\title{
RUSSIAN YOUTH ABOUT RUSSIA, UKRAINE, AND BELARUS - IMAGES OF COUNTRIES AND PEOPLES
}

\author{
Irina Snezhkova ${ }^{1}$
}

\begin{abstract}
The main goal of the present examination was to study the ideas of the Russian youth about Russia, Ukraine, and Belarus under existing social and political conditions. To this end, in 2018-2020, in a number of Moscow universities, sociological research was carried out, studying the images of Russia, Ukraine, and Belarus as perceived by Russian students. As far back as 30 years ago, the Russians, Belarusians, and Ukrainians had been perceived as three tight-knit ethnic groups within a broader category of East Slavs, but with the collapse of the Soviet Union, three independent states were formed, whose fates began to develop in different ways. At the present time complicated by all sorts of political controversies between the three countries under consideration, it seems important to know how these countries, their leaders, and peoples appear to the young people of Russia, what their attitude is to certain significant recent political events, namely the events in Ukraine, and to the opposition movement in their own country. The main research method was a sociological survey plus a certain amount of psychological testing. In total, 600 people were interviewed in several major universities in Moscow. The materials were then processed using the SPSS computer program. Also, the students were asked to present their perceptions of the country, its people, and its leadership in drawings, making the images as emblematic as possible. The results of the study showed that despite the difficult socio-political situation, Russian youth demonstrate a rather positive attitude towards their own country and its leadership; they regret the conflict in Ukraine, sympathize with its people, and condemn the ongoing civil war in the east of the country. Russians perceive Belarus as a friendly country with which it is necessary to strengthen cooperation. The research materials may be useful to specialists dealing with the ethnic issues in the three countries and with their political, economic, and cultural construction.
\end{abstract}

UDC Classification: 378, DOI: https://doi.org/10.12955/pss.v2.240

Keywords: Russian youth, images of Russia, Ukraine, and Belarus. Young people's perception of people and power, psychological testing, and sociological approach to the study of ethnic issues in a socio-political context.

\section{Introduction}

At the beginning of the 1990s, the unity of the East Slavic peoples - in Russia, Ukraine and Belarus seemed stable and unshakable. The collapse of the Soviet Union, and the signing of the Belovezhskaya Agreements did not signify any major interstate controversial issues. However, after 30 years, the situation has changed dramatically. Undoubtedly, the aggravation of the relations between Russia and Ukraine was caused by the "Revolution of Dignity" in 2013-2014, the transition of Crimea to the jurisdiction of Russia, and the civil war in eastern Ukraine. In the current situation, the question of the formation of a positive attitude of Russian society towards interstate and interethnic contacts is of fundamental importance. A special role in this process belongs to young people, in whose hands the future of our state is. The social potential of young people, their labor contribution to the economic development of society, their mobility and activity in maintaining contacts with peers on a global scale are factors that can contribute to the establishment of international contacts. (Shalygina, 2017) The main task of the present study was to trace, based on the results of polling Russian youth, their perception of Russia, Ukraine, and Belarus as countries, their attitude to important political events taking place in Ukraine and in their own country, as well as the young people's vision of the future relations of Russia with Ukraine and Belarus.

\section{A brief overview of the topic study}

In Russian science, fundamental studies of the country's image and perception began in the early 2000 s, encouraged by the need for the country to acquire the status of a renewed state, reborn after the chaos and misrule of the 1990s. The creation and promotion of the new image of Russia in the international arena were supposed to be based on advertising and communication technologies, and, first of all, on branding technologies proven out in the competitive environment of a market economy (Rozhkov, 2008). The very idea of branding the state, developed back in the 1950-1960s by the English founder of advertising agencies David Ogilvy, looked like a scheme based on sociological research that clarifies the "weak points" of the existing image of the state and the subsequent development of a holistic concept of its most attractive values and the creation on this basis of general positive background, without highlighting any one side of the country's life. In the second half of the last century, a similar scheme was successfully tested in the USA, Great Britain, Spain, and other

\footnotetext{
${ }^{1}$ The Institution of the Russian Academy of Sciences N.N. Miklouho-Maklay Institute of Ethnology and Anthropology, snezhkova@mail.ru, ORCID: 0000-0001-7247-4975.
} 
countries, increasing their attractiveness not only in the eyes of tourists, but also, which is no less important, in the eyes of the population of these countries, especially young generations who formed their own self-identification (Ogilvy, 2007).

In Russia, the study of factors that can influence the creation of a positive image of their country in the eyes of Russian youth began to be actively pursued in the second half of the 2000s. From the point of view of sociologist O.P. Gorbushina, Russian youth, like the youth of many other countries of the modern, high-tech era, are less susceptible to existing stereotypes due, first of all, to their "social infantilism" and clip consciousness, devoid of any deep historical-cultural reflection. Therefore, the most effective communication channel shaping the perception of the country's image by Russian youth are the media. (Gorbushina, 2006).

Moscow scientists, members of the Faculties of Political Science and Psychology of Moscow State University, have been actively developing a study of the country's image among young people by characterizing its political leaders and studying political power and national mentality. E.Shestopal, in his numerous articles and a textbook on Political Psychology (Shestopal, 2007), examines the perception of power depending on a subject's nationality. We studied such factors influencing the formation of the country's image as national identity, prejudices, and stereotypes. Methods for studying political problems with the help of sociological polls, focus groups, psychological tests were developed, including a method of psychological drawing of power and people and specific political leaders, which was used in the present study.

Belarusian scientists, in particular those from the Belarusian State University (Kalacheva, 2019), also point to the need to form the perception and image of the newly independent state of Belarus. Back in the early 2000s, an action program was adopted to develop a new image of the country, which has been comprehensively enriched over the past time. It includes, first of all, such components as the study of the artistic and historical uniqueness of cities and territories, the country's natural diversity, investment attractiveness, sports achievements, agritourism, as well as the study of the interaction of people and authorities in political science research.

Ukrainian colleagues from the Institute of Ethno-National and Political Studies named after Kourosa and their colleagues from the Russian Institute of Slavic Studies of the Russian Academy of Sciences actively developed in joint projects the topics of the countries' images, ideas about peoples, stereotypes in the context of Russian-Ukrainian relations. The project studies resulted in a number of conferences under the heading "Ukrainians and Russian: brothers, neighbors, competitors?" (Mironenko V.I. 2008). A similar study, concerning the transformation of ethnic identity in Ukraine and the formation of a new state image, was carried out by Miklukho-Maclay Institute of Ethnology and Anthropology of the Russian Academy of Sciences and the Ukrainian Institute of Art History, Folklore, and Ethnology of the National Academy of Sciences named after M. Rylsky. (Snezhkova, 2013) Unfortunately, the events of 2014, which in Russia are interpreted as an illegal coup d'etat, and in Ukraine as a Revolution of Dignity, interrupted mutual Russian-Ukrainian studies of the image and perception of independent states and the formation of a new national identity. However, there is still hope that the political situation will stabilize over time.

\section{Data and methodology}

When studying the perceptions by the young Russians of their own country and two other post-Soviet countries, an interdisciplinary approach was used that combines sociological, psychological, and anthropological theories. Continuing broadening the problematics studied in modern youth demands turning to new scientific paradigms that can provide explanatory models for the empirical data accumulated over the last decades. With the increased dynamic complexity of the post-Soviet Russian society, theories of the so-called integral meta-paradigm turned out especially useful in Russian sociology in the XXI c., explaining social development from the cultural pluralism perspective, and applying various, sometimes seemingly incompatible levels of analysis. Such a non-linear principle of looking at social phenomena allows post-Soviet sociology to offer convincing explanations of the complicated processes of the formation of new states on the territory of the former Soviet Union and the relationships between them. (Tishkov, 2006)

The study was conducted in Moscow in 2018-2020 among the students of the Department of Humanities (linguistics, psychology, translation, design) of the Moscow Information and Technology University; at the Department of Mathematics of the Moscow State Pedagogical University; at the 
Department of Fundamental Sciences of the N.E. Bauman Moscow State Technical University, at the Institute of Journalism and Literary Writing. These universities were chosen as some of the Russia's leading educational institutions, and as convenient survey venues.

The choice of universities was determined by their leading positions in education and the availability of the survey. A total of 600 people were interviewed. The main research method was a mass sociological survey. The questionnaire included 30 open-ended and closed-ended questions on the young Russians' perceptions of the three countries; in addition to questionnaires, a psychological picture test was conducted, often used in political psychology in studying the topic "People and power in the perceptions of young people" (Shestopal, 2007). In political and psychological research, it was important to find out how power is portrayed (with sympathy, or apathy, or antipathy). It was also necessary to understand what place the people occupy in relation to the power (located next to, centrally, below, or apart from the power symbols). We also assessed the plots and symbols used to depict the people and power, how they compare in size, and how close they are to each other. The study focused on the most frequently recurring plots. In addition, the role of the media, which is the main factor in the formation of young people's perceptions of the countries mentioned, was investigated (Malkova, Tishkov 2016).

\section{The role of the media}

The media play a very important role in shaping the political views of young people. For young people, the main source of information, in their own opinion, is the Internet (popular search engines being Google and Yandex), in particular, social networks - VKontakte, Facebook, Odnoklassniki, Instagram. The second most important source of information is the television. Paper media (newspapers, magazines) were mentioned by the respondents very rarely. When asked "How objective are the Western and the Russian media?" the overwhelming majority of respondents spoke about a bias and double standards, and about incidents of obviously cooked information in the media, especially the Western ones, when covering the situation in Russia (76\%). According to young people, the media are waging a hybrid war against Russia. Among the examples of disinformation, the youth named the coverage of events in Ukraine, in Syria, and in Russia. In their opinion, "the war between Ukraine and Russia" is "fake news", as in the actual fact there are no Russian troops in the east of Ukraine, which observers from Western Europe confirm, and it is the Donbas militias that are fighting there, defending their homes, that are shelled by the Ukrainian army. To quote some of the responses, "The use of chemical weapons in Syria has been repeatedly confirmed by the sudden resurrection of the dead, thanks to the staged footage of the White Helmets organization"; "The alleged Russia's interference in the US elections is ridiculous because none of the contenders for the role of US president suited Russia, as life has proved"; "the crash of a Malaysian Boeing over the Donbas was fabricated, if only because the weapons mentioned in the media had long been decommissioned in Russian armaments, which is recorded in many documents, it is the Ukraine that has them, though". In addition to the information war, we see that there is an active sanctions war against Russia. The main task of the sanctions is to weaken Russia economically and politically, to cause unrest on its territory, which would lead to a change of the president and government. Naturally, we raised the issue of the impact of sanctions on young people and the state itself. The responses were split $50 \%$ by $50 \%$. Young people pointed to such consequences of the sanctions as "price increases", "rise in unemployment", "disappearance of some imported goods," however, on the whole, they considered these facts to be insignificant. It should be noted that young people feel resentment and are psychologically tired of their Western partners' accusations of numerous offences that the country and its leadership did not commit.

\section{The image of Russia, according to the survey results}

To the question "What is your perception of Russia?" the most frequent answers were of positive nature (73\%). Young people see Russia as a "great superpower", "a strong country with great opportunities", "a country that has gone through great trials and overcame them", "a multinational state in which peoples live in harmony." Among the negative aspects in the image of Russia, young people noted "corruption of officials", "decline in living standards", "deterioration of education and health care", "discriminatory pension reform", "low salaries". To the question "Do you feel proud of your country?" the majority of young people's answers were affirmative (65\%). "Friendly, close-knit population," "a courageous people living on a vast territory," "a country that pursues an independent 
policy" are the most oft-recurring reasons listed to explain the pride. Since the world media currently demonize Russia, it was important to find out what kind of a country Russia should be, from the point of view of young people, in order to be attractive to other countries. Most of the respondents answered: "Russia should be economically and culturally developed, retaining its independence, united in spirit and in friendly communication with other countries."

The constant support of opposition movements from abroad made us ask a number of questions regarding the possibility of holding a "Maidan" on the territory of Russia, similar to the Ukrainian one. Among the young people surveyed 63\% denied the possibility of holding the Maidan at the present time; however, the majority (54\%) had a positive attitude to the presence of political opposition. The reasons for this were stated as follows: "so that politicians should not "venture too far", "so that the government knows the needs of the population", "so that there are various parties." At the same time, they did not talk about the leader of the opposition A. Navalny and his associates, the opposition was considered only in general terms, as a phenomenon. According to the respondents, the Maidan in Russia could be prompted by "a deterioration in the standard of living of the population," "ineffectiveness of reforms," "vigorous activity of the West to support the opposition". At the same time, as other studies have shown, young people believe that at the present time, pressure on Russian youth from Europe and America will increase in order to attract them to opposition activities and conduct a "color revolution" in the country (Gromov, 2012).

An important aspect of the study was to identify the attitude of young people to the adjunction of the Crimea to Russia. The majority of respondents (57\%) approved of this act, $23 \%$ were neutral, the rest were not interested in the topic (20\%). The respondents noted that the Crimeans held the referendum in accordance with all international rules, and that "the Russians tried to join the Russians." According to the respondents, the reason for joining was an illegal coup d'etat in Ukraine, the coming to power of an illegitimate government, which immediately proclaimed the Ukrainian to be a single state language, which alienated the Russian-speaking Crimeans living in the south and east of the country. Also noted were the brutal actions of the participants in the confrontation on the "Independence Square" and the fear of people getting into similar situations in the Crimea. (Other authors have touched upon this issue in their pieces on the Ukrainian referendum - see Guboglo, Starchenko, 2015).

Issues related to the situation in Donbas worried the youth, who sympathized with the residents of Donbas who have been under shelling for over six years, as well as with young Ukrainians who are fighting with their own civilian population, which their government passes off as Russian troops. The respondents noted the high-handedness of the Kiev authorities in relation to their own people, and the fact that there were lots of innocent victims among the civilian population. Some of the respondents viewed the war as a form of making money by the Kiev authorities. When asked how Russia should behave in this situation, the respondents suggested "promotion of reconciliation between the warring parties", and "implementation of the Minsk Agreements".

\section{The image of Russia in drawings}

The number of drawings returned was the same as the number of students surveyed, i.e., 600 pieces. The study found that in the majority of drawings (56\%) "power" was depicted favorably. In the drawings, power symbols were often placed centrally, with "people" close to it. The main leitmotif of most of the drawings was the union of the people and the authorities. The symbols depicting power are: a person larger in size than the "people". Also as symbols of power, images of animals were used - a bear, a traditional animal image of Russia, and a lion, a wolf, but what is characteristic is that there were their cubs ("people") nearby that the animals protected. There were quite a few drawings depicting a serene nature scene, people walking around the city or riding bicycles in the park, which supposedly testifies to the untroubled interaction of the people and the power elites. Certainly, there were drawings with a negative image of power (27\%), such as of police officers dispersing protesters at demonstrations. There were also drawings symbolizing the unjust distribution of income between the officials and ordinary people - for example, the image of a chicken leg, the pulp of which goes to the authorities, and the bone to the people. They were present in the drawings of truckfuls of money earned by the people but sent to the officials. The figures depicting the people were rather large, which testified to the perceived close distance between the people and the authorities. The drawings reflected the idea that the people rally around the president and work along with him. (Snezhkova, 2017) The current situation is often characterized by the presence of computer symbols as images of the 
interaction between the people and the authorities; for example, the people were depicted in the form of likes and smiling emoticons.

\section{The image of Ukraine, according to the survey results}

An important task of the study was to examine the Russians' perceptions of the Ukraine. Most of the students believed that things were going badly in Ukraine (89\%). Ukraine was called "a poor country, whose government had unleashed a fratricidal war." The existing government in Ukraine, according to the respondents, is "dependent, dependent primarily on the United States," as well as "aggressive and Russophobic," "Russia is blamed for all the Ukraine's troubles, while corruption is widespread in the country, gas, services, and utility bills are uncontrolled and growing"," television channels are closed for political reasons", "people who do not agree with the policy of the state are imprisoned", "the rehabilitation of fascism is encouraged." However, there were many answers sympathetic to the Ukrainians, connected with the fact that a conflict was unleashed in the country between kindred peoples, practically within a single people, which the respondents regretted. To the question "Does anything connect you with Ukraine?" The majority gave an affirmative answer (57\%), explaining it by "the parents' ethnicity, the presence of relatives and friends in Ukraine, a common history." To the question "Are you worried about the possible consequences of the Russian-Ukrainian conflict?" the most frequent answers suggested the fear that hostilities might be unleashed by the Ukraine and the collective West (48\%).

\section{The image of Ukraine in pictures}

Russian students generally criticize the relationship between the authorities and the people in the Ukraine. In many drawings, the authorities are depicted as not hearing the people, and even as encouraging fascism. In this connection, young people were often depicted marching with fascist symbols and being aggressive. Many drawings share a common idea of people earning the money and the government appropriating it. A lot of pictures speak of the dependence of the Ukrainian government on the United States and the European Union. Usually, a "hand" was depicted in such cases, stylized as the US flag, pulling the strings of puppets in Ukrainian costumes. Ukraine was often portrayed as a blazing bonfire; there were many drawings of a burning Ukrainian flag and flaming buildings. A lot of drawings, such as tank attacks on the Ukraine and the death of civilians in Donbas, depicted the civil war between Ukrainian troops and Donbas militias. There were also images of people galloping on the Maidan, chanting: "He who doesn't hop is a Moskal" (i.e., a Russian). In the depiction of the people's attitude to the authorities, computer symbols were widely used, the "like" sign turned upside down, and the smiley with a sad look.

\section{The image of Belarus, according to the survey results}

The image of Belarus in the perceptions of Russian youth is generally positive, the widespread answers are: "this is a country where order prevails", "all enterprises work", "agriculture is well developed", "there is a low crime rate" and "Belorussians have an everlasting president". Young people noted good relations between Russia and Belarus. Regarding the possibilities of the Maidan in Belarus similar to the Ukrainian one, the students answered that "under this president, this is hardly possible." Young people noted that "given the negative experience associated with Ukraine's departure from the East Slavic unity, it is necessary to increase political, economic, educational, cultural and tourist contacts among the youth of related countries. Also, young people noted a not always common position of Russia and Belarus on certain issues: "Between Russia and Belarus there is a constant bargaining in gas prices", "Sanctioned goods (products banned by Russia) are often transported through Belarus", etc. When asked about the future of Russia, Ukraine, and Belarus, the majority of young people's responses were, unexpectedly, optimistic (52\%). "The confrontation of the Slavic peoples cannot go on for a long time, they will find mutual understanding," "they were deliberately set against each other," "they will be in a single economic and political space such as the Customs Union." However, 43\% "doubted that it would be possible to establish a full-fledged contact with Ukraine in the near future, since "That country is supported by America, which is not good for the reunification of the three close peoples."

\section{The image of Belarus in drawings}

The pictured image of Belarus as seen by Russian youth looks rather favorable. As a rule, power is associated with the president, who is depicted as a large figure situated next to the people, suggesting Power's caring about people. The most common image of Belarus is a picture of harvesting or of 
plowed fields on which everything grows. People are working in the fields, and the president is working nearby. At one time, A. Lukashenko was a collective farm head, and he has always stood for supporting agriculture at the state level. Factories work, industrial products are manufactured. Sometimes the authorities are symbolized as a fist, or as policemen ready to put things in order. The research was carried out before the last presidential elections in Belarus in 2021 when A.Lukashenko had many opponents who accused his supporters of falsifying the elections. Time will tell how the situation develops within the country. Currently, the protests have diminished. The virtual computer image of power and people was positive, expressed in the signs of "like" and a smiley.

\section{Discussion}

As the study's general conclusion conducted in Moscow in 2018-2020 among higher school students, we can state that the Russian youth see Russians, Belorussians, and Ukrainians as three kindred peoples. For us, it was also important to know not only how young people describe the three kindred peoples but what feelings they have while doing so.

It is no secret that in addition to objective disagreements between countries, which are natural between any neighbors, there are certain far-fetched issues contrived by internal and external elites and broadcast through propaganda. It is always interesting to know to what extent the information that forms a country's image depends on real events and what perceptions are formed intentionally, guided in the "right" direction.

Specialists in interethnic relations investigate similar phenomena: they study the images of countries and peoples by examining auto- and hetero-stereotypes, studying the peculiarities of the formation of national and ethnic identities in newly emerged states, as well as monitoring the situation in border areas, etc. (Grigorieva 2020).

Our survey showed a high level of tolerance among our respondents, especially with regard to Ukraine, despite the fact that over the past 30 years, there has been active propaganda in the media suggesting the idea that Ukraine and Russia are antagonists. The recent events related to the civil war in Donbas and the annexation of Crimea by Russia, which brought about the perception of Russia as an aggressor country, have not changed the generally tolerant attitude of Russian students to the Ukrainian people.

Talking about the survey itself, we should note the technical difficulties in its implementation. It was not easy to gather the necessary number of respondents because the surveys, supposedly interfered with the students' studies, and teachers were reluctant to give up class time for sociological research, plus there are still restrictions related to the coronavirus epidemic. Nevertheless, in our opinion, the results of the study are objective enough, as they are largely consistent with other authors' conclusions.

In our opinion, in the future, similar studies should pay attention to the degree of tolerance between peoples, so that despite the existing differences, and taking into consideration the fact that international relations are largely built on a competitive basis in the field of economic and political dominance, rather than on the basis of common history and general human relations, a friendly attitude to other peoples should still be maintained.

\section{Conclusion}

The results of the study showed that despite the difficult political situation in Russia and in the world, the strong information and sanctions pressure on the country, Russian youth demonstrate a contained and largely positive attitude to the current situation. Young people in the mass support the policy of their president, although they are worried about what is happening in Russia and the world, fearing military conflicts. Responses concerning Russia and the Russian president were characterized by a mobilization trait. When Russia was accused of all mortal sins, a defensive reaction arose, expressed in a predominantly supportive attitude to the actions of the government and the president. The overwhelming majority of the respondents have a positive image of Russia as a superpower, a strong, united, multinational country with great opportunities. Ukraine appears as a country under external control and bogged down in its own military and civil conflict in the territory of Donbas, where citizens are dying. However, in many of the answers, there was sympathy for the Ukrainian people as kindred and suffering. Belarus is seen as a friendly country, stable and well-ordered, with a steady economy. Political unrest associated with the desire of a part of the Belarusian people to displace the 
country's president Lukashenko, is largely associated with his prolonged stay in power and the people's desire for change, as well as with the desire of external forces to change the main vector of the country's cooperation from Russia to the West. Despite all the difficulties in the political life of the countries under consideration, the Russian youth demonstrate a sympathetic understanding of the other peoples' situation and strive for a peaceful resolution of existing political problems.

\section{References}

Gorbushina O. P. (2006). The image of the country among Russian youth: structure and factors of formation M., 169

Grigorieva R.A., Demeter N.G., Gurko A.V. (2020). The Border and Identity: Culture and Ethnography of Belarus-Russia Borderline. Moscow. IEA RAS, 350.

Gromov D.V. (2012). Street Actions (Youth Political Activism in Russia): Russia. Moscow. IEA RAS., 506.

Guboglo M.N., Starchenko R.A. (2015). Referendum in Crimea on March 16, 2014: Russia. Moscow. IEA RAS, 314 .

Kalacheva I.I. (2019). The brand of the territory as a form of positioning the country // Modern youth and society in the dialogue of countries and cultures: historical experience and modernity. Minsk RIVSH, 17-23.

Malkova V.K., Tishkov V.A. (ED). (2016). Anthropology of Media: Theory and Practice: Russia Moscow: IEA RAS. 230.

Mironenko V.I. (2008). The image of Russia in Russian-Ukrainian interstate relations // Ukraine and Ukrainians: Images, representations, stereotypes. Collection of articles edited by Yu.A. Borisenok. M., Institute of Slavic Studies, Russian Academy of Sciences, 279-299.

Ogilvy D. (2007). About advertising. M., Eksmo , 160.

Rozhkov I., Kismereshkin V. (2008). Image of Russia. Resources, experience, priorities. M., RIPOL classic, 333.

Snezhkova I.A. (2017). Russia, Ukraine, Belarus, the European Union, and the United States as seen by Russian students: on the way to seeking mutual understanding. Bulletin of Anthropology. 4 (40), 87-97.

Snezhkova I.A (2013). Transformation of ethnic identity in Russia and Ukraine in the post-Soviet period. M, 196-222

Shalygina N.V. (2017). Ys and Centennials: New Mentality of Russian Youth. Power 1.164-167.

Shestopal E.B. (2007). Political psychology: A textbook for university students: Russia Moscow, Aspect Press, 427.

Tishkov V.A. (Ed.) (2006). Ethnological Monitoring and Early Conflict Warning. Moscow, IEA RAS.130. 